\title{
FUTURE OF ISLAMIC CIVILIZATION, EMERGING ISSUES AND NEW HORIZONS: A STUDY OF MALAYSIAN ISLAMIC MOVEMENTS
}

\author{
Sajid Iqbal Sheikh \\ Department of Islamic Thought and Civilization, \\ University of Management and Technology, Sialkot Campus \\ Muhammad Tahir Mustafa \\ Department of Islamic Thought and Civilization, \\ University of Management and Technology, Lahore
}

\begin{abstract}
This paper investigates four dimensions of Islamic Movements in Malaysian context. The first one is about the impacts of Islamic Movements instigating the development of Islamic civilization in Malaysia. Second one deals with emerging issues and modern trends in their futuristic approach and strategy. Third one evaluates sanity and diversity in issues and conflicts both in local and global perspectives. Finally, it examines the Western response and transformational role of the external world. General elections 2013 in Malaysia has marked a huge sign on the future politics of the country. National Front (BN: Barisan Nasional) faced major setback of fifty years in the history of Malaysian politics, government was unable to amend the constitution due to the absence of two third majority in the parliament because opposition collation Pakatan Rakayat (PR) grown more than fifty percent votes and more seats in federal and state legislative assemblies. Islamic Party of Malaysia (PAS) is one of the major fragments of opposition alliance. Among other Islamic organizations of the country PAS has achieved better growth and proved itself a distinguished Muslim political power of the country. Political process seems to be a better and safe way to achieve their ultimate goal of Islamic Resurgence for prominent Islamic movements of the world including PAS. We observe lot of bindings, barriers and challenges for them in different countries like, Egypt, Algeria, and Tunisia etc. The paper analyses ideological commonalities of different Islamic Movements of the world and concludes that specific circumstances demand certain approaches and finds out that Islamic movements asserting on peaceful process to attain massive support and handlings challenges both from world powers, Muslim secularists and radical youth groups.
\end{abstract}

Keywords: Islamic civilization, Malaysian Islamic movements, electoral process, militant wave

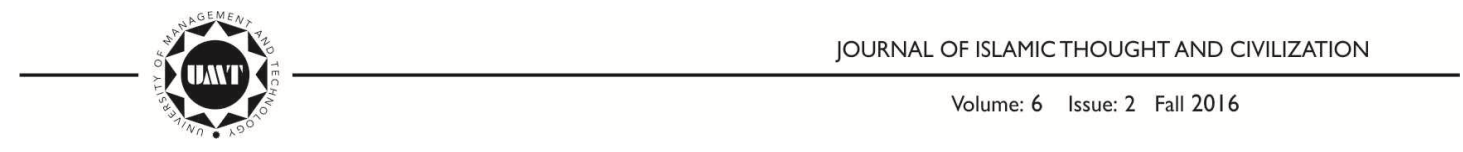




\section{Introduction}

There are two focal points of this paper in the special context of Malaysia and rest of the Muslim world in general. First one is about the issue of Islamic Civilization and second one is about the futuristic approach and strategies of Islamic Movements.

Islamic civilization, in recent years has been used in the context of some specific meanings, especially prominent Huntington's concept of "clash of civilization." This concept was followed by a debate in a large contrast among scholars and researchers round the globe. This paper tends to analyze its practical and implemented models in Malaysia. It specially discusses "Islam Hadhari" (Islamic Civilization) - a special terminology adopted by Abdullah Badawi - who ruled the Malaysian federation from 2003 to 2009. The paper will further analyze the backdrops and scheduling of the idea of Islam Hadhari and its offshoots and future.

Islamic Movement in Malaysia, according to this paper's prescribed understanding is particularly connected with PAS and to some extent with ABIM, the two major opposition parties of the country. PAS and ABIM are now exerting a joint venture as collation partners and getting more percentage of votes as electoral process is continuing in the country. PAS has its clear vision of emerging as an Islamic state where Islamic civilization according to the party perception will be transpired. This study is going to analyze political achievements of PAS in recent electoral history and in near future.

Islam as a whole and all Islamic resurgence movements in specific are painted through western influenced media as 'Terrorists,' 'Extremists,' and 'Fundamentalists' and with specific meanings 'Islamists.' While Islamic Movements are proving their commitment towards peaceful stance through involving dynamically in democratic and electoral process. They are facing resistance from the both sides, western powers, their secular Muslim allies and some radical Muslim groups who do not favor the peaceful plan of Islamic Movements and assert to adopt a violent scheme of combating their opponents. This study assesses the current scenario of the world in general and Malaysia in particular regarding futuristic emerging issues of Islamic Movement and new horizons.

\section{Islamic Movements of Malaysia: An Overview}

In Malaysia, Islamic Awakening began to rise before the end of 1960 with the development of Islamization process, which was somewhat impacted by the reasoning of the Muslim Brotherhood and other Islamic movements and thinkers like Syed Maudoodi, Hasan Al-Banna, Syed Qutb etc. The renaissance of Islamic Awakening prepared to secure an extensive social framework, which would ensure the advancement of Islamic solidarity in Malaysia. For example, the Muslim Youth Movement of Malaysia (ABIM) and a few others needed to create an Islamic culture taking into account the standards of Shari 'ah - showing Islam as al-dêen' (a way of

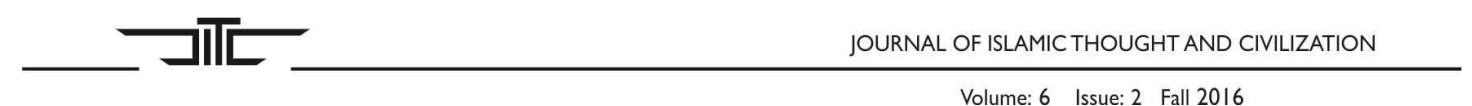

Volume: 6 Issue: 2 Fall 2016 
life). ABIM was the voice of youth in upgrading the stronghold of Muslim society the objective is to receive a lifestyle focused around the standards of Islam, to create temperance's and great deeds (امر با لمعروف)), and to keep the indecencies and awful deeds in the general public (نهى عن المنكر).

Essentially, the Islamic party in Malaysia (PAS) was secured with the perspective of making Malaysia an Islamic state. PAS needs to create a Malaysian culture by executing Islamic qualities and laws, and to advertise solidarity among individuals.

Lately, the new administration (Ulama) in PAS has helped the party by transforming its mentality, political vision, and methodology. Islamic developments in Malaysia are more politically arranged than that of different nations like Egypt, Tunisia, and Indonesia where the legislature and NGOs (rather than autonomous organizations) complete the vast majority of the demonstrations of Islamization.

There are various other Islamic establishments that fortify the methodology of Islamic Awakening in Malaysia. The International Islamic University Malaysia (IIUM) and Institute of Islamic Thought and Civilization (ISTAC) were fortified with a perspective to blend the present day scenario and Islamic instruction framework.

The halal food initiative in Malaysia has been turned out to be a financially feasible apparatus, and has pulled in expansive number of purchasers from diverse parts of the world to devour clean and hygienic sustenance. Also, the Islamic need of managing an account and budgetary dealings has pulled in local banks as well as international banks in Malaysia. This is because of the way that individuals are intrigued in working together that would not prompt sin. By and large, Islamic Awakening pushes solidarity and welfare in the plural and multi-ethnic society of Malaysia.

We can divide Islamic restoration movements in Malaysian society in different phases:

1. The time of starting transformation to Islam, which demonstrated a clearing change in a conviction framework from polytheism to Islamic monotheism.

2. The time of living in autonomous Muslim sultanates, this blended Islamic convictions and practices with pre-Islamic Malay traditions and values.

3. The approach of rigid and reformist developments expected to clean the convictions and practices from non-Islamic gradual additions, superstitions, and degenerate supernatural quality.

4. The battle against European colonialism that heightened the awareness of $j i h \bar{a} d$ as religiously propelled outfitted safety against remote colonizers.

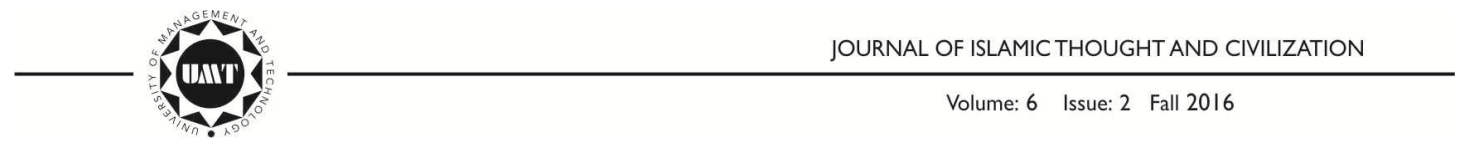




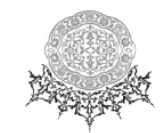

5. The post-colonial period saw the ideological and political battle between reform-oriented Muslims and the Secular-based political powers. It was in this period that the thought of an Islamic state was at first talked about as an answer for the imperviousness to the patriots' inclination for a political framework and government in which religion did not play a significant or determinant role. In the seventies, the thought of Islam as a complete lifestyle (دين) and not only a religion in the western feeling of the expression was generally upheld by reformist Muslim educated people and Islamic youth developments because of the secularizing tendencies of the westernizedadministering elites, who were realizing changes for the sake of modernization and national advancement. Daawah (welcome to Islam) then turned into the new approaches of Islamic reformist activism.

6. The Islamic resurgence of post-1979, the Islamic uprising in Iran impacted a few Islamic developments in Malaysia - particularly PAS and ABIM. Islamic developments, political gatherings, and youth associations in Malaysia got another wave of life and another certainty among the Muslim groups in Southeast Asia.

Islam approached the Malay Peninsula in the fifteenth century. It was at the outset generally appreciated and acknowledged just by Malay blue-bloods, yet got to be to a greater degree a general character marker in the nineteenth century when vast amounts of non-Malays started to move to Malaysia and an Islamic revival in the 1970s, happened came to be known as the "Daawah Movement." As a result, ABIM came into being in 1970s. ABIM furnished Muslim youth with a way to look after daawah through educational institutions and in general society circles. In the words of Ioannis Gatsiounis,

The major consequence of this "rebirth," "reassertion," or "rediscovery" of Islam was that Islam came to be seen as the pillar of Malay identity. The Dakwah sought to resist the pressures of modernization, reinvent and reconstruct tradition, express antiimperialist sentiment and promote spiritual renewal. External forces such as the Iranian Revolution and the Dakwah (Dawah) movement in neighboring Indonesia breathed fresh life into Malaysia's Dakwah, as did, around the same time, the appointment of Mahathir Mohamed to the post of prime minister in 1981. In the course of his 22-year rule he would oversee Malaysia's dramatic transformation from an agrarian backwater into an industrialized export-driven nation (Malaysia is the U.S.'s 10th largest trading partner). The era would also be scarred by a politically charged, sanctimonious battle for the soul of Islam. ${ }^{1}$

ABIM and PAS both parties were considered as Islamic movements of Malaysia but there are slight differences between them. Both parties ultimately became opponent to UMNO. Both has criticized the ruling regime headed by UMNO

\footnotetext{
${ }^{1}$ Ioannis Gatsiounis. "Islam Hadhari in Malaysia." Current trends in Islamist ideology 3 (2006): 78-88.
}

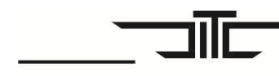

JOURNAL OF ISLAMICTHOUGHT AND CIVILIZATION 
leadership and has proved themselves major political strengths of the country as prescribed by Ahmed Fauzi Abdul Hamid,

\begin{abstract}
Among established Islamic movements, the Muslim Youth Movement of Malaysia [ABIM] and Islamic Party of Malaysia (PAS) bore the brunt of the government's repressive legislation during the formative phase of Islamic resurgence. ABIM was then arguably the most vocal critic of government policies among NGOs and the epitome of the new socio-political force of dakwah, while PAS was an open competitor against theUnited Malays' National Organization (UMNO) for Malay-Muslim votes. ${ }^{2}$
\end{abstract}

In the case of Malaysia, the move took the shape of increasing curiosity in religion, or maybe better to say, the Islamic segment of the Malay identity. Although, sanctioned by the ruling establishment, the movement had a vibrant antiestablishment stance, recognized with disapproval of the American action in Vietnam and with the condemnation of imperialism in general, and inclined to find meaning and interest in the rediscovery of Islam. Many movements appeared, but three, particularly, have accumulated the utmost attention.

\title{
2.1. Jamat Tabligh
}

Jamaah Tabligh is a worldwide Islamic daawah movement. ${ }^{3}$ It is most likely the most far reaching Islamic movement on earth despite the fact that the real number cannot be confirmed because of the extremely casual nature of the movement. Jamaah Tabligh was established at 1926 in India by Muhammad Ilyas Al-Kandhalwi. Jamaah Tabligh has its practice as it was a compulsory part of Islam. Jamaah Tabligh is a non-political party and has dependably been so. They proclaim that with a specific end goal to change the society/ government we initially need to change the single person. Small groups of Jamaah Tabligh go out to different mosques to practice daawah. There, they fundamentally read Jamaah Tabligh, ${ }^{4}$ help one another to remember the Sunnah and go around the mosque population to ask individuals to come to the mosque for a discussion in which they essentially discuss Emaan (يمان). Jamaah Tabligh has a tradition to go out for 3, 7, 40 days or 4 months. They finance themselves and have no enrollment or participation expenses or any formal ties.

\footnotetext{
${ }^{2}$ Ahmad Fauzi Abdul Hamid,. "Patterns of State Interaction with Islamic Movements in Malaysia During the Formative Years of Islamic Resurgence," in South East Asian Studies 44, no. 4 (2007): 444 - 465.

${ }^{3}$ The term "Islamic Movement" generally used for all Islamic organizations having massive influence but mostly used for those religio-political movements across the Muslim world which struggle to establish an Islamic state in their respective countries. Its main tool in this struggle is political mobilization of the masses. The paper does not refer to that section of Islamic Movement to those contemporary groups who employ violent means for their political ends. [Shahbaz Ahmad Cheema, "Problematizing the Religious Basis of Maududi's Political Theory," Studies on Asia Series IV 3, no. 2 (2013).]

${ }^{4}$ Tableeghi Nisab is a book authored by Mulana Zikria $(R A)$ one of the founders of Tableeghi Jamaat. The book comprises different Ahadees and narratives about importance of good deeds.
}

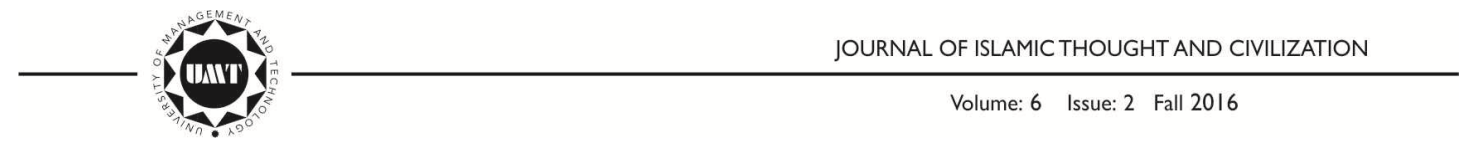




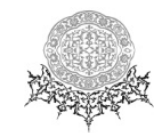

Jamaah Tabligh just contacts Muslims while non-Muslims are not their target. Different associations had blamed Jamaah Tabligh to that validity of their philosophy on Hadith and their practice is questionable. Some comment on that Jamaah Tabligh is veered off. These condemning individuals are most presumably from a political party, as Jamaah Tabligh does not help any political plan. ${ }^{5}$

\subsection{Dar-ul-Arqam}

In addition, Darul Arqam is yet another movement. It was established in 1968 by annex government school teacher and political worker of Malay, Ashaari Muhammad. Much more cultic than Jamaat Tabligh, Darul Arqam made is an Islamic commune on a land comprising eight acres near Sungei Penchala village situated outside Kuala Lumpur. No less than 40 other communities, 200 schools, charitable associations and dispensaries were the forerunner of the commune specializing in the "Islamic" rehabilitation of young drug-addicts. ${ }^{6}$

Like Jamaat Tabligh which had a particular lifestyle, Darul Arqam made it mandatory to its followers a particular appearance like, Arabic style wear, turbans and to be habitual of eating by hands, avoidance of furniture like tables, chairs, and televisions etc- it necessarily diverged by demanding them to live in a barred community, dissimilar from the society. Self-reliance was a main objective of Darul Arqam, and the promotion of halal food and other Islamic merchandises arose as a significant characteristic of the cluster that qualified it to grow into a prosperous business initiative with offices all over Southeast Asia. At the stage of its clamp down in 1994 it was assessed to comprise about 10,000 members and resources valued around 120 million US dollars.

Openly apolitical, similar to Jamaat Tabligh however, was intrinsically perilous of the greater society in which it hunted to yield root. Severely analytical of other Islamic organizations in Malaysia, about which Ashaari Muhammad stated only theorized, chanted slogans, and held seminars, Darul Arqam pursued to recreate a "true" Islamic communal through a formal rejection of the bigger society in which it existed.6

\subsection{ABIM (Angkatan Belia Islam Malaysia)}

More imperative than either Jamaat Tabligh or Darul Arqam, in the longer run, was the Malaysian Islamic Youth Movement - "Angkatan Belia Islam Malaysia" (ABIM) that, as it blossomed and ripened, played a progressively

${ }^{5}$ Historical Chronology of Evolution of Tablighi Jamaat http://tablighijamaattruth.blogspot.com/2013/05/tablighi-jamaat-history-tareekh-islam.html (Accessed on 31-07-2014)

${ }^{6}$ Max L. Gross, A Muslim Archipelago: Islam and Politics in Southeast Asia (Malaysia: Government Printing Office, 2007)

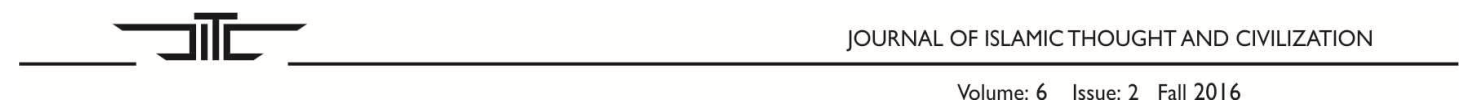


significant political role in Malaysian culture. Officially announced in 1971 at the country's then the single University of Malaya with objective of "building a society that is based on the principles of Islam," ABIM had a rapid growth and proclaimed membership of 40,000 in addition to many other supporters by the early 1980s. Getting its strongest support from Malay youth in Malaysia's establishing institutions of higher learning in the 1970s, particularly in the country's extremely advanced and urbanized states in the west (viz. Negeri Sembilan, Selangor, and Perak), ABIM might have accomplished success because of its relatively academic and rational appeal.

Jamaat Tabligh and Darul Arqam for aiming at "mindless ritual practices" and "unthinking obedience to Shari "ah law," ABIM placed its emphasis on monetary and public distresses, how to accomplish justice in these areas, and how to make Islam a lively way of life. Study circles, seminars, academic sessions, and other scholastic venues, particularly those activities so severely criticized by Darul Arqam, were main ABIM activities that assisted to increase the awareness of members, smooth negotiation among them, and stimulate them to have a profound understanding of Islam and concerns affecting the country. Deeply influenced by the instances of Jamaat-i Islami in Pakistan and the Ikhwan al-Muslimūn (Muslim Brotherhood) of Egypt, both Islamic Movements denounced contemporary secularism and its political appearance, nationalism, ABIM took a firm stand against the National Economic Policy (NEP) sponsored by UMNO, which it perceived as an appearance of Malay nationalism. As an alternative, it supported the steady conversion of Malaysia into an Islamic state, ruled by the Shari'a which; it contended, was fundamentally and factually culturally-diverse in essence and intended at accomplishing social justice for all ethnic groups of the society. In Economic perspective, ABIM claimed that government must target helping the deprived from all segments of society, not from the Malays only. ${ }^{7}$

Regardless of an original intent to maintain itself as a civil society association, essentially distant from political affairs, like "Jamaat Tabligh" and "Darul Arqam," ABIM was quickly drained into a political starring role. It can be argued that this might be due to the magnetic leadership of Anwar Ibrahim, one of "ABIM"s founders. He was just 25 years old in 1971 at the time of its existence. Later on he became its head from 1974 to 1982. Regardless of his objective to perform a mainstream political role or not, his control of the party brought him into the focus, steered to his administrative co-optation with the Premier Doctor Mahathir Mohammed in 1982, and his appearance as Mahathir's ultimate successor earlier to being crudely dropped from indulgence and converted into a criminal behind bars in 1998. Possibly a more substantial reason behind ABIM's ascent into political relevance was the fruitful

\footnotetext{
${ }^{7}$ Max L. Gross, A Muslim Archipelago: Islam and Politics in Southeast Asia (Malaysia: Government Printing Office, 2007).
}

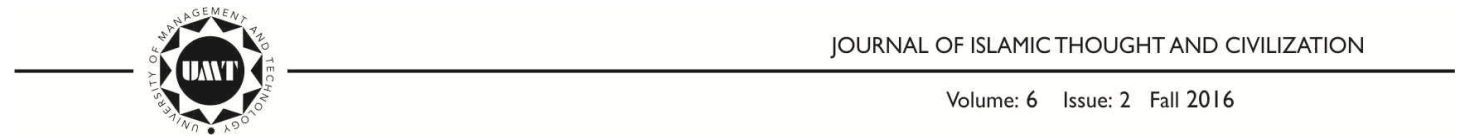


UMNO co-optation in 1972 of Malaysia's main Islamic political party, the "Parti Islam SeMalaysia" (PAS), into the extended 10-party "Basilan Nasional" (National Front) alliance that continued to lead Malaysia politically in the years after the May 1969 unrests in Kuala Lumpur. Though PAS vindicated its stance to join the "Basilan Nasional" on the grounds of strengthening Malay unity in order to enforce the NEP, its joining the alliance had the impact of removing it from its customary role of opposition to the UMNO at a time of rapid Islamic revival in the country. The disappearance of PAS from its traditional resistance role created a space that ABIM was in a position to fill. ${ }^{8}$

\subsection{Parti Islam Se-Malaysia (PAS)}

PAS (Parti Islam se-Malaysia) was formally established earlier than Malaysian freedom from British colonialism on November 24, 1951. PAS was at first an extension of UMNO, which was fortified in 1946 by the Malay Partisan Movement and was planned to unite the Malay-Muslims of the nation in foresight of independence. Not withstanding the ordinary party members, the early party was contained of three major zones - the Dewan Ulama (Ulama Council), Dewan Pemuda (Youth Wing), and Dewan Muslimat (Women's Wing) - all of which remain today. Although they had their own committee, the Ulama did not wield extraordinary impact in the party until a few decades after its existence. PAS and UMNO formally disjoined ties when PAS' second president, Dr. Elias Abbas, authoritatively enlisted the party on May 31, 1955, one and only week prior crusading for Malaysia's first federal government election, held in July 1955, started. When PAS got to be completely free from UMNO, it proposed to serve as an immediate check to the UMNO's more liberal strategy. ${ }^{9}$

PAS leaders objected to the secular nationalist inclinations of UMNO and from the start articulated their objective of making an Islamic state out of Malaysia. PAS power was embedded in the economically disadvantaged, mainly Malayinhabited northern and eastern states, particularly Kelantan and Terengganu, both of which the party gained political control in the first country-wide elections in 1959. At the same time, PAS was more patriot Malay than was UMNO, but because it opposed the more secular and nationalist thinking of UMNO, it had no choice but to stress the Islamic feature of Malay nationalism.

${ }^{8}$ Ibid

${ }^{9}$ Erica Miller, "Democratic Islamists? A Case Study on the Pan-Malaysian Islamic Party (PAS)," (MA Dissertation, The Fletcher School, Tufts University, 2006), 22. http://dl.tufts.edu/catalog/tufts:UA015.012.DO.00125 Accessed on 23-07-2014

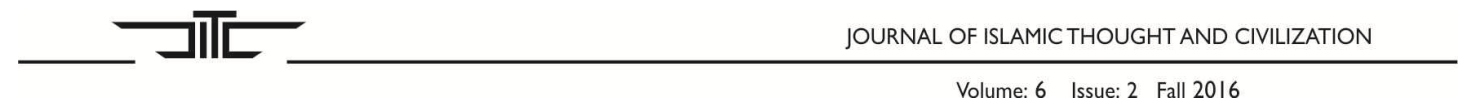




\title{
3. Islamic Civilization: An Overview of Malaysia
}

\begin{abstract}
Although Mahathir certainly saw Malaysia as a "model" Muslim country, Abdullah's Islam Hadhari concept took it one step further by crafting a broad philosophy designed to appeal to domestic Muslim and non-Muslim audiences as well as Muslim populations abroad. ${ }^{10}$
\end{abstract}

On October 31, 2003, following 22 years Prime Minister Mahathir resigned and was supplanted by Abdullah Ahmad Badawi, an UMNO pioneer who was considered to have extraordinary Islamic accreditations. Since entering office, Badawi grasped a plan of Islam Hadhari (Civilizational or Progressive Islam) as a method for proceeding with UMNO's Islamization of government and countering the political test postured by PAS. The allure of Islam Hadhari to numerous Malaysian Muslims, PAS' conceded carelessness and haughtiness in dealings with coalition accomplices, and the general structural difficulties confronting opposition parties in Malaysia, cost PAS a sizeable appointive setback in the 2004 general elections where its national Parliamentary representation dropped from 27 seats to 7.

Ioannis Gatsiounis ${ }^{11}$ comments on the Badawi's initiative of Islam Hadhari and states that this initiative aims to make alignment between Malays and rest of multi-ethnic and multi-faith populations of Malaysia,

Islam Hadhari is to some extent a logical outgrowth of social, political and Islamic realities in Malaysia. The government has long stressed moderation and economic equity in order to keep peace between the Muslim Malays, who make up about 60 percent of the population, and the indigenous tribes and sizeable Chinese and Indian minorities, most of whom are not Muslim. Malay concerns, however, have always been central to government policy. ${ }^{12}$

He further argues that the innovator of "Islam Hadhari" tends to make Malaysia a modern, democratic and economically prosperous country through this ideology,

But Islam Hadhari should not be viewed merely as a political instrument. Prime Minister Badawi envisions Islam Hadhari as an antidote to the tide of extremism ravaging the larger Muslim world, at a time when many Muslim nations are struggling to reconcile piety with modern realities. "It is our duty," Badawi said at a

\footnotetext{
${ }^{10}$ Andrew Humphreys, "Malaysia's Post-9/11 Security Strategy: Winning "Hearts and Minds" or Legitimising the Political Status Quo?". Kajian Malaysia 28, no. 1 (2010): 21-52.

${ }^{11}$ Ioannis Gatsiounis, A New York native, is a Malaysia-based journalist and author whose recently released debut of fiction, Velvet and Cinder Blocks, details a planned attack on a Christian landmark in Malaysia. His blog is breaklines.wordpress.com; http://www.globalpost.com/bio/ioannisgatsiounis Accessed on 07-08-2014

${ }^{12}$ Ioannis Gatsiounis, "Islam Hadhari in Malaysia," CurrentTtrends in Islamist Ideology 3 (2006): 78-88.
}

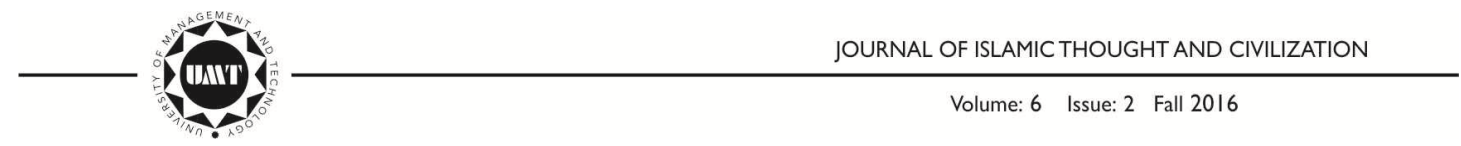


conference last year, 'to demonstrate, by word and by action, that a Muslim country can be modern, democratic, tolerant and economically competitive.", 13

According to the findings of Ioannis Gatsiounis, some people perceive the idea of Islam Hadhari as a political strategy against Islam-based political motives of some strong political parties of the country,

Some observers count Islam Hadhari's vagueness among its strengths - to be vague is to be inclusive. As a general concept Islam Hadhari makes for a legitimating canopy against crude efforts to Islamize Malaysia. It provides an accessible terminology to counter Muslims who claim that the only way tobe a good Muslim is to support the full implementation of sharia law. Islam Hadhari does not seek to be a doctrinal equivalent to the prescriptive, ritualistic nature of fundamentalism. Rather, says Badawi, it is a practical approach consistent with the tenets of Islam. According to Boston University's Robert Hefner, "Badawi is coming out and showing people in long gowns that you can welcome Americans and investment and still be a good Muslim. ${ }^{14}$

Abdullah Badavi and other supporters of Islam Hadhari present the idea as a balanced and modern concept, which focuses on economic, social and political development. Dr. Mohamed Sharif Bashir from Islamic University of Science, Malaysia states the idea of Badawi as under,

According to Badawi, Islam Hadhari, or civilization and comprehensive Islam, is not an inclusive concept as it also emphasizes the importance of progress-with an Islamic perspective-in the economic, social, and political fields. Islam Hadhari emphasizes the need for balanced development, which covers both physical and spiritual development. Hence, Badawi proposes a holistic development approach for Malaysia. This means a shift in development approach from a "secular paradigm" to a "tawheed paradigm," which emphasizes developing a thinking society, social harmony, and economic progress. ${ }^{15}$

According to him the main characteristics of Islam Hadhari are comprehensive and wide in range. He asserts that total concept of Islam Hadhari is based on Islamic grounds. All of its components are obligatory in Islamic way of life. Some of them are,

Universality: It is based on Islam, a universal message for mankind that is based on mercy. Godliness: It is based on divine scripture and works on bringing people closer to their Lord. Hence, it is a godly end and means, and has a divine source and reference. Morality: Its ultimate concern is maintaining a good character and good human relations. Tolerance: Tolerance is essential to create a society based on peace, stability, unity, cooperation, and solidarity among all it segments and with all its

\footnotetext{
${ }^{13}$ Ioannis Gatsiounis, "Islam Hadhari in Malaysia," Current Trends in Islamist Ideology 3
} (2006): 78-88.

${ }^{14}$ Ibid.

${ }^{15}$ Mohamed Sharif Bashir, "Islam Hadhari: Concept and Prospect," Islam Online 3 (2005).

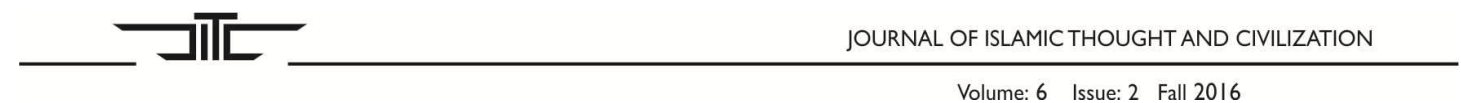


different traditions and beliefs. This kind of tolerance is based on trying to genuinely understand the other and respect cultural and religious convictions. ${ }^{16}$

These are the trademark characteristics of Islam Hadhari that recognize it from the various significant points of view;

1. Comprehensiveness: It coordinates both scripture-based sciences and contemporary sciences. An alternate peculiarity is its all-incorporating project to manage the individual, society, and the state.

2. Moderation: This is the fundamental philosophy for the viewpoint, which is focused around gradualism and ease in execution. Through this execution, there will be a harmony between the benefit of all—the individual and the general public, divine and worldly needs, and beliefs and reality.

3. Diversity: The setting of Islam Hadhari is wide in range; it covers an extensive variety of interests on diverse levels; it is open to new conformities and to other human practices.

4. Humanity: As a call, Islam Hadhari is centered upon people.

Abdullah Badawi himself elaborates his concepts in these words,

I would like you to know that this approach has also been inspired by our firm belief that good governance, healthy democratic practices, empowerment of the citizenry through education and equitable sharing of the benefits of economic growth will remove any attractiveness towards radicalism and blunt any tendencies towards extremism. We in Malaysia would like to show by example that a Muslim country can be modern, democratic, tolerant and economically competitive. ${ }^{17}$

To spread the Islam Hadhari logic, the government, through the Information Ministry's Special Affairs Department, propelled a five-year action. Headed by a board made up of religious scholars, writers, scholastics, jurists and analysts, the movement included 600 speakers dispersing information on the idea to the general public through different discussions. Outlining the centrality of Islam Hadhari to the administration's ideological reserve, in 2007 Abdullah gave an RM 50, 000cheque to each Member of Parliament, Muslim and non-Muslim the same. The funds might be utilized for canvassing in the forthcoming elections.

Moreover, this philosophy has been extensively used to convince the people in the perspective of 9/11. The ideologies of Prime Ministers Mahathir Mohammad and Abdullah Badawi both endeavored to manage the terrorist beliefs, universally and

\footnotetext{
${ }^{16}$ Abdullah Badawi, "Islam Hadhari and Good Governance," speech, Victoria University, Wellington, 31 March 2005; Andrew Humphreys, "Malaysia's Post-9/11 Security Strategy: Winning "Hearts And Minds" Or Legitimising The Political Status Quo?" Kajian Malaysia 28 (1) (2010): 2152.

${ }^{17}$ Ibid.
}

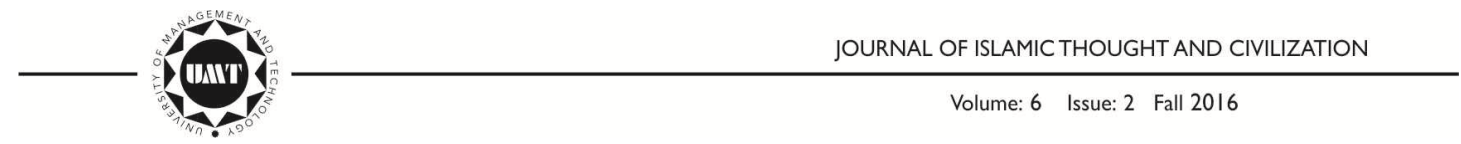




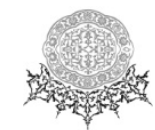

locally, and in doing so used a security arrangement which mixed force and philosophy. Each one prefaced his ideological reaction on a manifestation of Islam which pushed, most importantly, the government's funds. Mahathir served Malaysia as a leading Muslim nation and endeavored to discuss "moderate" Islam in the post9/11 context. A large number of Mahathir's plans were repackaged and marginally retooled in Abdullah's Islam Hadhari venture. There are components to be appreciated in the ideological methodologies of both Prime Ministers. The ideological methodology of both the leaders was most concerned with keeping up the local political norms. The techniques of both was to cutoff the ideological space of their rivals and utilize $9 / 11$ as a guide to further limit the talk on Islam in their nation. While universally and locally the Islamic themes of Mahathir and Abdullah were elevated as endeavors to unite the Muslim world against terrorism and undermine the impact of radicals.

An expert on Malaysian and southeastern Islam, Fouzi Abdul Hamid states that Abdullah Badawi's concept of Islam Hadhari was perceived by opposition Islamic parties and their supporters as, "But it was not long before Islam Hadhari ignited defensive reactions from conservative Islamists, many of whom bore the misleading impression that Islam Hadhari was merely a cloak for liberalizing Islam." 18

He finally concludes that the concept of Islam Hadhari was outdated and drowned with the premiership of its creator Abdullah Badawi,

As Abdullah Badawi's administration staggered from 2006 onwards, it became ever clearer that Islam Hadhari's failure was inevitable, given its disappointing disconnect between theory and practice, between what was portrayed as lofty civilisational ideals and poor implementation by religious officials who had neither knowledgedriven inkling of it nor concern over its future. In short, even before Abdullah's tenure as Prime Minister had reached its expiry date, Islam Hadhari was already a spent force. His command of BN and UMNO to disastrous election results in 2008 tarnished his reputation forever, thus practically putting a halt to Islam Hadhari. As soon as it became obvious that Islam Hadhari would not be able to survive Abdullah's embattled Premiership, its death knell was sounded by outspoken figures from the religious bureaucracy and from all sides of the political divide. ${ }^{19}$

${ }^{18}$ Abdul Hamid Fauzi, and Muhamad Takiyuddin Ismail, "Islamist Conservatism and the Demise of Islam Hadhari in Malaysia." Islam and Christian-Muslim Relations 25, no. 2 (2014): 15980 .

${ }^{19}$ Ibid.

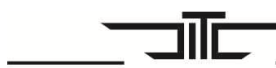

JOURNAL OF ISLAMIC THOUGHT AND CIVILIZATION 


\title{
4. Future Trends
}

Ahmad Sunawari Long ${ }^{20}$ indicates that Malay Muslims are adopting Islamic practices through the academic and practical activities of Islamic Movements which at one level collaborate globally,

\begin{abstract}
Regarding to the religious practices, it is common now-a-days, the most of Muslim middle class attend religious activities such as group prayer and religious circle. Result from this research showed that most of the participants pray at their workplace (regularly-12.8\%), attend weekend religious circle (49.8\%) which current issues and writings of religious reformist such as Hassan al-Banna of Egypt regularly discussed, recite the Qur'ān (37.1\%) and perform pilgrimage to Mecca (6.5\% regularly go to Mecca). ${ }^{21}$
\end{abstract}

\section{Islam: A Core Issue of Malaysia}

Malaysia is a multi-ethnic nation embodying three principle ethnics, namely Malay, Chinese and Indian. After Malaysia accomplished freedom, the first attempt towards integrity was to bring together political parties namely United Malay National Organization (UMNO), Malaysia Chinese Association (MCA) and Malaysian Indian Congress (MIC). On the other hand, this recent development makes changes especially in Malay political parties which are UMNO, PAS (Pan-Malaysia Islamic Party) and PKR. If Malay political parties are scattered then what about the endeavor to build national state? In the consequences of these latest developments, media assumes a vital part by declining the current emergency. Each one of those situations has demonstrated that common developments additionally guarantee for a more fair managing framework and race which challenges the legislature on the issues of solidarity and country state.

Nationalism is no more a core issue of Malaysian political sphere. Does it mean that continuous struggle of Islamic movements in this multi-ethnic and even multi-religion country has drawn impact on political scenario? Let's overlook research outcomes of a research. ${ }^{22}$ Malay political power is gradually weakening as being said by political observers. Malay privileges as stated in the constitution are becoming distracted. The circumstances become complicated with the confrontations towards country's leadership like BERSIH demonstration, jostling for power and internal Malay political conflict. This anxiety of political Malay will hinder the construction of nation state. National integrity is being observed as something which is hard to achieved and yet become a crucial issue in Malaysia. This series of dispersal among Malays has failed the idea of Malaysia's nation state. This is due to the Malays, who as the aborigines and the major ethnic in the country still cannot tolerate to each other and fail to unite. Fauzi Abdul Hamid investigates the

\footnotetext{
${ }^{20}$ Associate Professor in Philosophy and Islamic Research Methodology. Currently at National University of Malaysia https://www.blogger.com/profile/08095342748514858177 Accessed on 07-08$\underline{2014}$
}

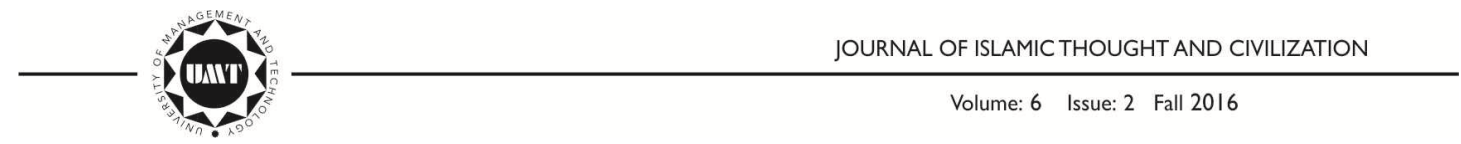




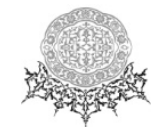

premiership period of Dr. Mahathir which was 22 years long by discussing its impact on Islamic revivalism in these words,

An invariably important determinant of Malaysian society, Islam has been fore grounded in the country "political dynamics since its putative resurgence in the 1970s. Muslim - non-Muslim relations became a perennial fault line with potentially explosive consequences for the whole polity. During the Premiership of Dr. Mahathir Mohamad (1981-2003), the state undertook piecemeal Islamisation via incentives and measures to counterpoise the challenge emanating from such Islamist rivals as the opposition Islamic Party of Malaysia (PAS: Parti Islam SeMalaysia) and independent social movements especially the Muslim Youth Movement of Malaysia (ABIM: AngkatanBelia Islam Malaysia), Darul Arqam and Jamaat Tabligh." 23

\section{Dedication Towards Democratic Process}

Erica Miller, in her case study on PAS Malaysia, finds out that the Islamic Party is committed to bring change only through the democratic and electoral process,

While PAS has clearly demonstrated its commitment to electoral politics by its regular participation in elections since 1955, many see the mere existence of elections as not necessarily constituting the existence of true democracy. On the cynical side, PAS could be described as selectively embracing democratic principles based upon the extent to which they serve the party's ultimate objective of creating an Islamic state. ${ }^{24}$

She also states that PAS leadership has opposed continuously all illegal and violent activities and always expressed their commitment to wards constitutional and peaceful activities,

As the party's message has evolved, it has expressed its certainty that the principles of Islam are fundamentally compatible with democracy. Following the arrest of several suspected militants in Malaysia in August 2001, Nik Aziz underscored PAS' commitment to cooperating with authorities to undermine militancy, saying that the party would "never resort to undemocratic means to achieve its political struggle." He added that any PAS member who violently opposes the government would be expelled from the party. ${ }^{25}$

${ }^{21}$ Ahmad Sunawari Long, Wan Fariza Alyati Wan Zakaria, and Indriaty Ismail. "A Case Study in Klang Valley, Malaysia." The Social Sciences 8, no. 1 (2013): 1-4.

${ }^{22}$ Suhana Saad, Lyndon N., S. Selvadurai, M. S. Sarmila, are research scholars of Faculty of Social Sciences and Humanities, Universiti Kebangsaan Malaysia, Bangi, Malaysia

${ }^{23}$ Abdul Hamid Fauzi, and Muhamad Takiyuddin Ismail, "Islamist Conservatism and the Demise of Islam Hadhari in Malaysia," Islam and Christian-Muslim Relations 25, no. 2 (2014): 15980.

${ }^{24}$ Erica Miller, "Democratic Islamists? A Case Study on the Pan-Malaysian Islamic Party (PAS)," http://dl.tufts.edu/catalog/tufts:UA015.012.DO.00125 Accessed on 23-07-2014

${ }^{25}$ Ibid., 60.

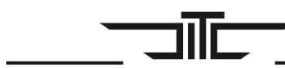

JOURNAL OF ISLAMICTHOUGHT AND CIVILIZATION 


\section{Comprehensive Message of Islam}

Islamic movements of present world e.g. Muslim Brotherhood in Arab world, Jamaat-e-Islami in Sub-Continent, Prosperous Justice Party of Indonesia and PAS Malaysia etc., are struggling hard within the framework of their respective constitutional boundaries. Simultaneously, we may not find any deviation from commitment towards their ultimate goal of Islamic renaissance. Hence, basic ideology behind this concept is that Islam does not hold any separation between the religion and politics.

Syed Abul'ala Maududi ${ }^{26}(1903-1979)$ is considered one of the most influential thinkers of the modern Islamic Movement. He clearly demonstrates that there is no separation found between the state and religion in the basic resources of Islam and this is a religious obligation for a Muslim to do struggle for the purpose of Islamic revolution. As prescribed by Cheema ${ }^{27}$ in these words,

His political theory revolves around the idea that religion and politics are an inseparable entity and the fulfillment of religious dictates is impossible unless and until we organize a political system as per criteria set by the religion. This idea of Maududi has led many to believe that it is our religious duty to struggle for an Islamic state like many other religious obligations, e.g. offering prayers and keeping fasts. ${ }^{28}$

We also observe impacts of Maududi's thought in policy making of PAS Malaysia. PAS present president asserts that this is their core viewpoint that there is no separation between religion and the politics,

Current Parti Islam Se Malaysia President Hadi Awang self-classified the party as an Islamist group by saying, "In Islam, religion cannot be separated from politics."The above assessment of the group's evolution, agenda, and orientation corresponds with this general classification, but where does PAS fit in among the wide variety of Islamist groups? Employing R. Stephen Humphreys' Islamic ideal classifications, PAS can best be characterized as a hybrid of "fundamentalist" and "modernist." 29

Muzzafar Hussain expresses his research outcomes on Syed Maududi by finding different evolving steps of Maududi's political thought. Maududi has elaborated his vision of Islam in such logical way and he has a complete picture of

\footnotetext{
${ }^{26}$ Maulana Syed Abul'ala Maududi (1903-1979) founded Jammat-e-Islami in 1941 at Lahore, India (now Pakistan). His ideology about Islam as complete code of life (Deen) is seems spread worldwide. He authored more than 100 books. Many of them have been translated to dozen languages of the world. Islamic Movements of the present era unanimously consider Maudoodi their master mind.

${ }^{27}$ Dr. Shahbaz Ahmad Cheema, Assistant Professor, Faculty of Law University of the Punjab Lahore, http://faculty.shahbaz-ahmad-cheema.pu.edu.pk Accessed on 07-08-2014

${ }^{28}$ Shahbaz Ahmad Cheema, "Problematizing the Religious Basis of Maududi's Political Theory," Studies on Asia Series IV 3, no. 2 (2013)

${ }^{29}$ Erica Miller, "Democratic Islamists? A Case Study on the Pan-Malaysian Islamic Party (PAS)," http://dl.tufts.edu/catalog/tufts:UA015.012.DO.00125 Accessed on 23-07-2014
}

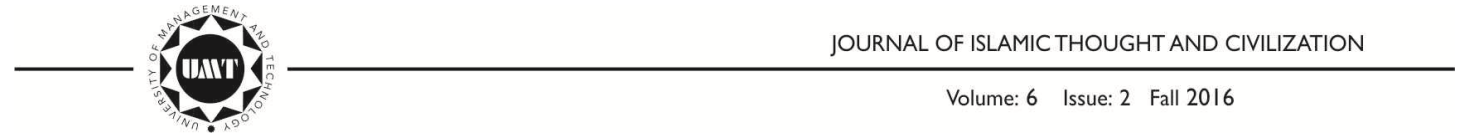


Islamic revolution, Islamic state and understanding in such words, "In presenting his alternative, Mawdudi first explains his understanding of Islam. Then he derives principles of the Islamic system from this understanding. Further, he discusses the importance of Shari' $a$ as a guide of Islamic polity, and finally he briefly maps out an institutional scheme of his perceived Islamic state."

Maududi states it clearly that Islam in its true nature and spirit does not favor any separation between religion and politics. Islamic way of life basically stands on this clear vision of integration. After the independence of Pakistan, Quid-e-Azam Muhammad Ali Jinnah (Founder of Pakistan) invited Maulana Maudoodi to deliver some lectures on national radio of Pakistan about the fundamentals of Islamic way of life. He started his discussion with such words, "The chief characteristic of the Islamic Concept of Life is that it does not admit a conflict, nay, not even a significant separation between life spiritual and life-mundane. It does not confine itself merely in purifying the domain extends to the entire gamut of life." 31

\section{Emerging Issues and New Horizons}

Western diplomats, policy makers and researchers have different views about the Malaysian Islamic Movement in particular and other Islamic movements in general. They are keen observers of occurrences of the Muslim world. On the contrary, Islamic Movements have also different views about the Western people, their policy makers and their power-holders. Government policies of the US and other European countries are generally criticized by the leaders of the Islamic movements. Especially their invasion of Iraq and Afghanistan raises several question marks on their fame. Patronization of Israel by the west does nothing but enhances a notorious view of the Western regime. PAS leadership too is very much concerned on the western role in Malaysia and other countries of Muslim Ummah. Erica Miller overviews the PAS strategy regarding different actions of the Western regimes about the Muslims,

PAS has been critical of U.S. political and military influence in Malaysia. The party spoke out against U.S. military aid to Malaysia and joint U.S.-Malaysian military exercises saying such activities would lead to American interference in Malaysian sovereignty and national defense. Following the Bali bombings in Indonesia, PAS held a similar line calling for non-interference by the United States in the Indonesian investigation. Additionally, PAS blamed the Malaysian federal government's crackdown on PAS-run madrassas on undue U.S. influence in domestic affairs. Before former U.S. Secretary of State Colin Powell visited Malaysia, the PAS Youth Wing issued a condemnation of the visit saying that it would hurt Malaysia's image

\footnotetext{
${ }^{30}$ Muzaffar Hussain, “The Islamic Polity of Abdul a'la Maududi,” in VFast Transactions on Islamic Research 3(1), (2014): 13-21; Muzzafar Hussain from Jawaharlal Nehru University New Delhi, India

${ }^{31}$ Abul Aala Maududi, "Islamic Way of Life," ScribeDigital. com, last modified. March, 2012, http://scribedigital.com/
}

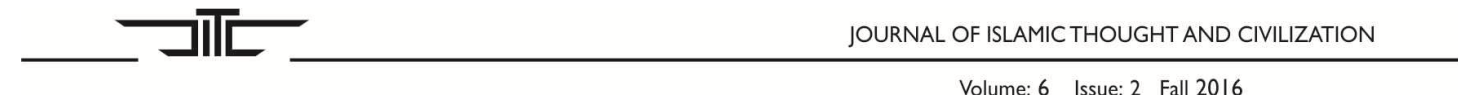


because "the United States itself is the main initiator of terrorism throughout the world. $^{32}$

In contrast with PAS policy, we also evaluate comments of a former American diplomat Ronald Palmer about Malaysia and its Islamic political parties,

However, the strongly islamized, largely rural poor Malay population resented being left behind economically. Many turned to the fundamentalist Pan Malaysia Islamic Party better known by its acronym, PAS, as an alternative to UMNO. Since it was formed in 1950, PAS has unapologetically advocated an Islamic state based on Koranic law and has criticized the secular orientation of the modern state the UMNO has organized. On November 12, 2003, PAS announced its goal of an Islamic state, which would incorporate sharia law, including stoning and amputation as punishment for criminals. Mahathir Mohammad strenuously sought to maintain Malay unity by keeping PAS off-balance with a mixture of cooperation, co-option and coercion. PAS gained control of Malay majority states Kelantan and Terengganu in the 1999 elections and also made gains at local levels. It now heads the Opposition in Parliament. $^{33}$

\section{Terrorist Wave and Islamic Movements}

Post 9/11 world scenario is facing a serious wave of terrorism. Western influenced thinkers blamed that all the Muslim groups are involved in such terrorist activities. Contrarily, all Islamic movements of the world are committed to follow the constitutional and democratic process to achieve their ultimate goal of Islamic revolution. Western treatment with the issue is creating serious threats to the world peace. Jamaat-e-Islami Pakistan ${ }^{34}$ arranged a three days conference of World Islamic Movements in September, 2013 at Lahore. A statement issued by Syed Munawar Hasan then the Chief of Jamaat-e-Islami Pakistan declares,

World colonialism led by the US was foiling all efforts for world peace. The life, property and honor of the Muslims all over the world was insecure. Colonial powers

${ }^{32}$ Erica Miller, "Democratic Islamists? A Case Study on the Pan-Malaysian Islamic Party (PAS), " 70 .

${ }^{33}$ Ronald Palmer "Why Muslim Terrorism Exists in Southeast Asia," http://www.unc.edu/depts/diplomat/item/2005/0103/palm/palmer_seaterr.html Accessed on (31-072014) The following article was updated from a presentation made by Ambassador Palmer at the Villanova University Africana Program in November 2003. The author, a retired career diplomat, served as U. S. ambassador successively to Togo, Malaysia, and Mauritius, in addition to other senior positions in Washington and abroad during his thirty-two year Foreign Service career. A member of the American Diplomacy Publishers board, he is now professor emeritus at The George Washington University.

${ }^{34}$ Jamaat-e-Islami (also written Jamaat-i-Islami or abbreviated JI) is Pakistan's oldest religious party. The JI ranks among the leading and most influential Islamic revivalist movements and the first of its kind to develop an ideology based on the modern revolutionary conception of Islam in the contemporary world.JI's intellectual inspiration primarily came from thoughts of Maulana Sayyid Abul A'la Maududi, who along with the great thinker poet Dr. Mohammed Iqbal, set the pace for contemporary Muslim thinking in the South Asian sub-continent. JI was established in Lahore on August 26, 1941 http://www.globalsecurity.org/military/world/pakistan/ji.htm Accessed on 07-08-2014

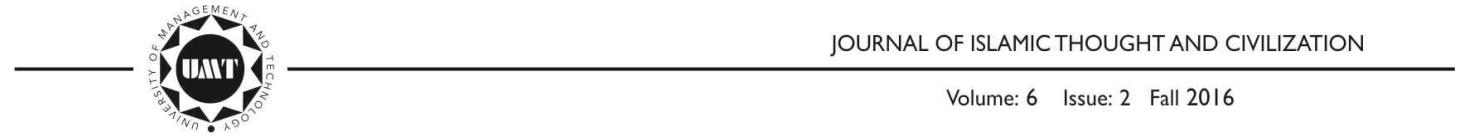


were interfering in Muslim countries and engineering terrorist activities. Millions of Muslims had been killed in Iraq and Afghanistan, while drone attacks had killed thousands in this country. The US and NATO had begun an undeclared war against the Muslims. He said the US had been supporting dictators in the Muslim world in order to obstruct the rule of the Islamic movements, and Algeria, Sudan, Palestine and Egypt were the examples. In Egypt, the US had openly supported a military general in ousting an elected government, and the military regime had killed thousands of peaceful protesters demanding the restoration of the democratic government. $^{35}$

At the closure of the conference, a unanimous declaration was issued as a guideline for the Muslim Ummah and specially its youth. The emphasis was on the issue that despite aggression against Muslims in the whole world, they have to focus on peace,

The moot had been convened by the Ameer, Jamaat e Islami, Pakistan, Syed Munawar Hasan to assess the challenges being faced by the humanity at large and the Muslim Umamh in particular, especially the ouster of the elected government of Dr Muhammad Mursi in Egypt and the bloodshed in Syria, and also to decide a line of action for steering mankind and the Muslim Ummah from the Representatives of Islamic movements from Jordan, Malaysia, Sudan, Morocco, Tajikistan, Turkey, Somalia, Palestine, Tunis, Algeria, Sri Lanka, Nepal, Yemen, and Held Kashmir, attended the In its joint declaration, the conference condemned the attacks at worship places of the and the killings of innocent people, and said that a true Muslim could neither tolerate oppression nor do any wrong to anyone. It is said that only the antiIslam forces were behind such incidents. It stressed upon the Muslim youth to refrain from violence and Vendetta and continue their struggle with reason and prudence. The joint declaration also emphasized that Islam is the religion of peace and the Muslim Ummah was the messenger of goodwill and wellbeing for humanity. ${ }^{36}$

In the special context of Malaysia, we may observe that an important part of worldwide Islamic Movements, PAS has repeatedly echoed that it is not a militant group and sustained to stress upon its refusal of terrorism and violence as means for accomplishing its goals. It has also supplemented that it does not tolerate terrorism more generally as "it is not the way to solve problems."

PAS leaders do not recommend militant activities. We have given strong responses saying we do not agree with any violent means. In spite of its strong criticism of the United States, it has formally condemned and expressed compassion for the victims of terrorist instances, including the Bali bombings, September the 11 attacks, and London subway bombings of 2005. On September 11, then-PAS President Noor said, "PAS regards any attack on properties and lives of the public,

\footnotetext{
${ }^{35}$ Questions and Answers from Munawar Hassan" http://www.munawarhasan.com/en/answers.php?id=560 Accessed on 31-07-2014

${ }^{36}$ Islamic moot resolves for peaceful struggle, condemns all forms of tyranny http://www.thenewstribe.com/2013/09/26/islamic-moot-resolves-for-peaceful-strugglecondemns-all-forms-of-tyranny/ Accessed on 31-07-2014
}

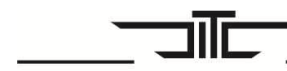

JOURNAL OF ISLAMICTHOUGHT AND CIVILIZATION 
including innocent children, women, and the aged, whether on American soil or any other part of the world as heinous crimes." 37

\section{Conclusion}

By an exhaustive discussion on two focal points namely the issue of Islamic Civilization and the futuristic approach and strategies of Islamic Movements, it may be concluded that Malaysian political process is an example for the rest of the Muslim world, where democratic process is going on since its freedom in 1957 from British Colonialism. This continuity has empowered political infrastructure of the country. Islamic civilization in general is a detailed structure of daily life according to the injunctions of basic sources of Islamic paradigm, Quran and Sunnah. "Islam Hadhari" was produced as a tool to address the fear of the population of opposing Islamic party PAS. Though, Badawi was benefitted from the idea of Islam Hadhari in elections 2004 yet, in the results of GE 2008 and 2013, the idea seemed fallen down and quite unable to strengthen UMNO.

Moreover, overview of the GE 13 reveals that first time in the history of the Malaysian elections, BN (National Front) was unable to hold $2 / 3$ majority and opposition PR alliance received more votes and less power, but better than ever before. Despite other important national and multi-ethnic parties, role of ABIM and PAS is comparatively observed puffed-up. This shift is another obvious modern trend.

Futuristic approach regarding the political scenario of Malaysia is difficult to predict because every election campaign carries different issues and results. Post GE 13 situation depends upon the strategies of both the ruling and opposition collation parties and their leadership. It is being assumed by the political analysts that after achieving better strength of Malay voters the opposition PR alliance might be in better position to attain ultimate goal of the control of Federal Government. This forecast depends on the behavior of the ruling and opponent regimes as well.

As an Islamic Movement PAS role is very much vital in this whole scenario. PAS has proved that it has a firm belief on peaceful, constitutional and democratic process to achieve its ultimate goal of Islamic state. Having a major role in some important provincial governments, PAS leadership is obviously much interested in getting more roles in the future. It is also important that GE 13 has proved that PAS is more tolerant with their ideologically opponent allies like DAP etc.

New trend of deviation from the democratic process and adopting violent from some young groups of sidelines is becoming a rapid challenge to all stakeholders including Islamic Movements, external regimes and researchers. World renowned Islamic movements including PAS are committed to follow and adopt peaceful,

${ }^{37}$ Erica Miller, Democratic Islamist? A Case Study on the Pan-Malaysian Party, (2006), 70.

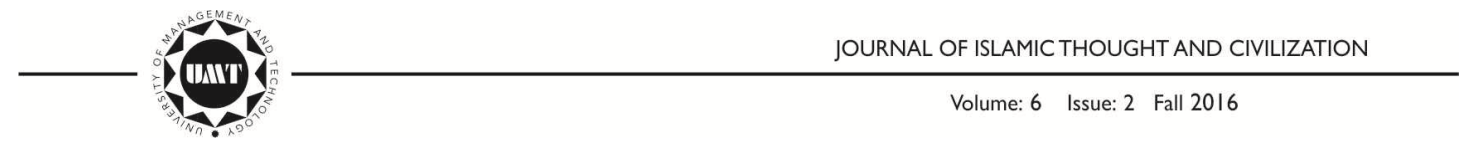




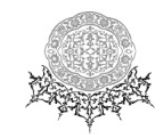

constitutional and electoral means around the world, despite a quit vice versa response from the external and internal regimes in the special context of Algeria, Egypt, Tunisia, and Palestine.

In the history of Malaysian Islamic struggle, many youth groups emerged and tried their best to adopt secret and illegal ways to hold their ambitions like, Jamah alIslamia, KMM (Kulalampur Mujahdeen) etc. These groups basically reflect militancy in a very smaller circle of Malaysian youth. We also observe that such type of approach has been observed and faced by almost all major peaceful Islamic movements of the world. We can also find that after every assault on peaceful Islamic movement like military coup against Muhammad Mursi Government of Egypt in July 2013 and Al-Nahdha party of Tesunia, Muslim armed groups feel easy to recruit more youth to strengthen their respective plans. These parties (Islamic Movements) achieved victories through political process but they were bound to be escaped from the power due to their clear Islamic agenda. Recent attacks of Israel on Gaza Strip have enhanced militant approach in Muslim youth round the globe because they feel that they can save Muslim lives only through armed movement. Islamic Movements believe and support armed activities only in the Muslim territories occupied by the Non-Muslim powers as like Palestine, Kashmir, Afghanistan, Iraq, and Chechnya. They do not support any armed movement in the countries where constitutional and democratic struggle for Islam is admissible.

Malaysian Islamic Party PAS has strongly condemned armed activities of such groups who are of the view that through combativeness they can achieve the ultimate goal of Islamic state and revivalism. It is a further obligation of researchers of the field of Islam to conduct some new researches on the waves of armed movements in the Muslim youth, its root causes and solutions. Simultaneously, it is a cutting edge need to analyze the principal logics and roots of non-political and non-democratic Islamic organizations; some of them have massive influence e.g. Jamaat Tableegh, Hizb-ul-Tehreer etc.

Finally, it is observed that future of Islamic civilization is equally crucial for Islamic Movements as well as rest of the world. Islamic movements are trying their best to achieve their destination through logic, rational, peaceful struggle and communication (Tableegh or Dawah). Despite aggression and hurdles (both practically and theoretically) from anti-Islam regimes, secularist Muslims and so called Islamo-phobia networks, their past and present leadership is committed and contented on legal, democratic and constitutional process in their respective homelands. They are also facing constant emerging issue of diversity and deviation from their pacific struggle by a very short circle of youth who favors al-Qaida, Jamah Islamia and Taliban's confrontational ideology. This phenomenon calls the researchers to unfold and analyze the roots of these all ideologies; political, nonpolitical and belligerent.

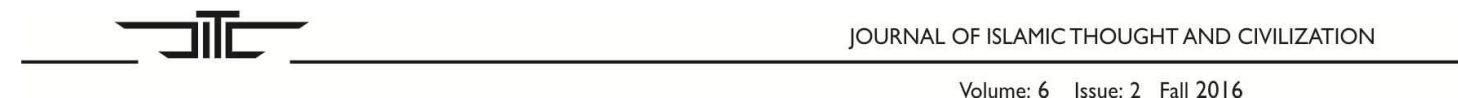

Volume: 6 Issue: 2 Fall 2016 


\section{BIBLIOGRAPHY}

Abaza, Mona. Debates on Islam and Knowledge in Malaysia and Egypt: Shifting Worlds. Psychology Press, 2002.

Baharuddin, Shamsul Amri. "A Revival in the Study of Islam in Malaysia." JSTOR, 1983.

Bashir, Mohamed Sharif. "Islam Hadhari: Concept and Prospect." Islam Online 3 (2005).

Cheema, Shahbaz Ahmad. "Problematizing the Religious Basis of Maududi's Political Theory. "Studies on Asia Series IV 3, no. 2 (2013).

Chinyong Liow, Joseph. "Political Islam in Malaysia: Problematising Discourse and Practice in the Umno-Pas 'Islamisation Race.'" Common wealth and Comparative Politics 42, no. 2 (2004): 184-205.

Chong, Terence. "The Emerging Politics of Islam Hadhari." Malaysia: Recent trends and Challenges (2006): 26-46.

Fauzi Abdul Hamid, Ahmad, and Muhamad Takiyuddin Ismail. "Islamist Conservatism and the Demise of Islam Hadhari in Malaysia." Islam and Christian-Muslim Relations 25, no. 2 (2014): 159-80.

Gatsiounis, Ioannis. "Islam Hadhari in Malaysia." Current trends in Islamist ideology 3 (2006): 78-88.

Gross, Max L. A Muslim Archipelago: Islam and Politics in Southeast Asia. Government Printing Office, 2007.

Hamid, Ahmad Fauzi Abdul. "Patterns of State Interaction with Islamic Movements in Malaysia During the Formative Years of Islamic Resurgence." South East Asian Studies 44, no. 4 (2007): 444-65.

Hamid, Ahmad Fauzi Bin Abdul. "Islamic Resurgence in the Periphery: A Study of Political Islam in Contemporary Malaysia with Special Reference to the Darul Arqam Movement 1968-1996." (1998).

Humphreys, Andrew. "Malaysia's Post-9/11 Security Strategy: Winning" Hearts and Minds" or Legitimising the Political Status Quo?" Kajian Malaysia 28, no. 1 (2010): 21-52.

Huntington, Samuel P. The Clash of Civilizations and the Remaking of World Order. Penguin Books India, 1996.

Hussain, Muzaffar. "The Islamic Polity of Abdul A'la Mawdudi." VFAST

Transactions on Islamic Research 3, no. 1 (2014): 13-21.

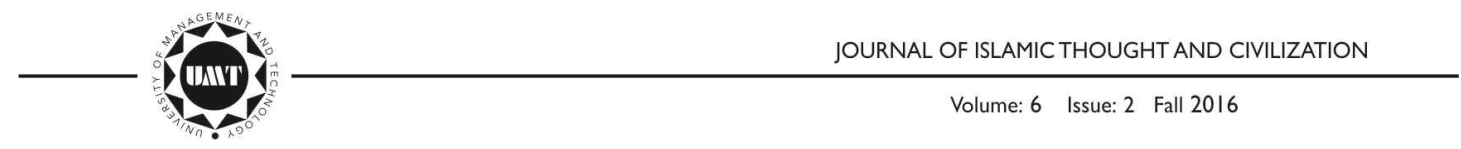




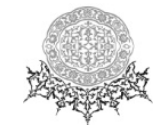

Long, Ahmad Sunawari, Wan Fariza Alyati Wan Zakaria, and Indriaty Ismail. "A Case Study in Klang Valley, Malaysia." The Social Sciences 8, no. 1 (2013): $1-4$.

Maududi, Abul Ala'. Islamic Way of Life. ScribeDigital. com, 1997.

Moten, Abdul Rashid. "2008 General Elections in Malaysia: Democracy at Work." Japanese Journal of Political Science 10, no. 01 (2009): 21-42.

Mueller, Dominik. Islam, Politics and Youth in Malaysia: The Pop-Islamist Reinvention of Pas. Vol. 65: Routledge, 2014.

Müller, Dominik M. "An Internationalist National Islamic Struggle? Narratives Of'brothers Abroad'in the Discursive Practices of the Islamic Party of Malaysia (Pas)." South East Asia Research 18, no. 4 (2010): 757-91.

Noor, Farish. The Malaysian Islamic Party Pas 1951-2013. Amsterdam University Press, 2014.

Rahman, Saodah A, and Abu Sadat Nurullah. "Islamic Awakening and Its Role in Islamic Solidarity in Malaysia." American Journal of Islamic Social Sciences 29, no. 1 (2012): 98-125.

Saad, Suhana, N Lyndon, S Selvadurai, MS Sarmila, R Zaimah, and AM Azima. "Malay Politics and Nation State in Malaysia." Asian Social Science 9, no. 8 (2013): 96.

Yong Liow, Joseph Chin. "Exigency or Expediency? Contextualising Political Islam and the Pas Challenge in Malaysian Politics." Third World Quarterly 25, no. 2 (2004): 359-72.

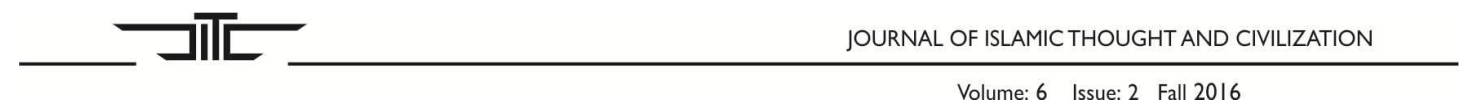

